\title{
WT1 Gene Mutations in Chinese Children With Early Onset Nephrotic Syndrome
}

\author{
JIANGUO LI, JIE DING, DAN ZHAO, ZIHUA YU, QINGFENG FAN, YAN CHEN, HONGWEN ZHANG, XUHUI ZHONG, \\ JIANPING HUANG, YONG YAO, AND HUIJIE XIAO
}

Department of Pediatrics, Peking University First Hospital, Beijing 100034, People's Republic of China

\begin{abstract}
In Chinese children with steroid-resistant nephrotic syndrome (SRNS), it was reported that NPHS2 mutation was detected in $4.3 \%$, which was lower than that in Caucasians (10-30\%). However, there were no data on WT1 mutation in nephrotic syndrome (NS), especially in early-onset NS of Chinese children. Thus, a study, which enrolled 36 Chinese children with early-onset (before 3 y old) NS and steroid resistance if failing steroid therapy (early-group), was conducted. As control, 35 children with SRNS and with disease onset age after 3 y old were also analyzed (control-group). WT1 gene was examined by PCR and direct sequencing. The result showed that in the early-group $6 / 36(16.7 \%)$ were detected with WT1 mutations. Further analysis according to different onset age revealed that the mutation detection rates of WT1 were $26.3 \%$ (5/19), 6.3\% (1/16), and $0(0 / 1)$ in children younger than $1 \mathrm{y}, 1-2 \mathrm{y}$, and $2-3 \mathrm{y}$, respectively. In control-group, no WT1 (0/35) mutation was detected. WT1 mutation combined with NPHS2 variant was detected in a girl. In conclusion, WT1 mutations seemed more common in Chinese children with early-onset NS. (Pediatr Res 68: 155-158, 2010)
\end{abstract}

$\mathrm{N}$ ephrotic syndrome (NS) is often a life-threatening condition when manifesting as early-onset, especially in the first year of life. In recent years, several causative genes related to NS have been identified by applying molecular genetic approaches, including NPHS1, NPHS2, WT1, LAMB2, PLCE1, ACTN4, TRPC6, and CD2AP (1-8). These genes have been analyzed in a large cohort of patients with NS worldwide, especially NPHS1, NPHS2, and WT1. The results suggested that, in these genes, NPHS1 mutations were mainly detected in children with congenital NS (CNS), and WT1 and NPHS2 might be more common in children with primary steroid-resistant nephrotic syndrome (SRNS) (9-11). As to WT1 gene, previous studies by other groups revealed that the incidence of WT1 mutations in isolated SRNS children (6.8 y in average age) was $6-7 \%(9,10)$, and the two hot spots were exons 8 and 9 in WT1 gene. Nevertheless, there were few reports on the incidence of WT1 mutations in children with early-onset NS, especially in the first year of life. In China, there are numerous children with early-onset NS for whom neither the incidence nor clinical characteristics of WT1 gene

Received October 8, 2009; accepted April 7, 2010.

Correspondence: Jie Ding, M.D., Ph.D., Department of Pediatrics, Peking University First Hospital, No.1, Xi An Men Da Jie, Beijing 100034, People's Republic of China; e-mail: djnc_5855@126.com

Supported by Major Program of National Natural Science Foundation of China (30830105), National Natural Science Foundation of China (30672259, 30801250), Beijing Municipal Natural Science Foundation (7072080), and National 11th Five-year Scientific and Technical Supporting Programs (2006BAI05A07). mutations are clear. The identification of gene mutations associated with early-onset NS will definitely help Chinese childhood patients to obtain the correct diagnosis, to prevent excessive drug therapy, and to obtain the suitable genetic consultation. Therefore, we detected WT1 mutations in a large cohort of children with early-onset NS and analyzed the phenotypic characterization in children with WT1 mutations.

\section{METHODS}

Patients. A total of 36 unrelated children of Chinese ethnicity with early-onset NS (within $3 \mathrm{y}$, early-group) was enrolled in this study. There were $30 / 36$ children in the early-group who received steroid therapy (1.5-2 $\mathrm{mg} / \mathrm{kg}$ daily for $8 \mathrm{wk}$ ) and presented with steroid resistance. The other 6/36 cases had not received steroid therapy for the early onset age younger than 4 mo (including five cases with CNS). All children of early-onset NS were further divided into three groups according to the onset ages, younger than $1 \mathrm{y}, 1-2 \mathrm{y}$, and 2-3 y, respectively. Some of the infectious diseases resulting in CNS were excluded through screening blood serum antibodies of toxoplasma, rubella virus, cytomegalovirus, herpes simplex virus, and syphilis. Another 35 SRNS children with onset age more than 3 y were enrolled as a control-group in this study. All the children both in the early-group and the control-group were diagnosed between 2003 and 2008. The study was approved by the Ethics committee of Peking University First Hospital, Beijing, China (2006023). All the parents provided informed consent.

WT1 mutation analysis. Genomic DNA was extracted from peripheral blood cells from probands and their parents by standard methods (12). Direct sequencing of exons 8 and 9 in WT1 gene was performed. For those children suspected of having hereditary NS, including 5 with CNS and a boy with NS combined with cryptorchidism, other exons of WT1 gene were also analyzed. Using Primer 3 software, the primers of WT1 exons 1-10 were designed as done in our previous studies (Table 1) (12). The PCR for WT1 exons 2-10 were performed in $25 \mu \mathrm{L}$ consisting of $12.5 \mu \mathrm{L} 2 \times$ Taq plus Master Mix (Tiangen Biotech, Beijing Co., Ltd.), $1 \mu \mathrm{L}$ sense primer $(5 \mu \mathrm{M}), 1 \mu \mathrm{L}$ anti-sense primer $(5 \mu \mathrm{M})$, and $1 \mu \mathrm{L}$ DNA $(50 \mathrm{ng} / \mathrm{L})$. Takara La TaqE (5 MU/L) and $2 \times$ GC Buffer II were used in the PCR reaction for the GC-rich WT1 exon 1. The amplification was performed using Touchdown PCR with an annealing temperature from 64 to $58^{\circ} \mathrm{C}$, descending $1^{\circ} \mathrm{C}$ every two cycles, and subsequent annealing at $58^{\circ} \mathrm{C}$ for 26 cycles. The PCR products were visualized by $2 \%$ agarose gel electrophoresis and sequenced using the ABI $3730 \mathrm{XL}$ DNA Analyzer (SinoGenoMax Company Ltd). WT1 gene in probands' parents was also analyzed if mutations of WT1 were detected in the proband. All mutations were confirmed by two independent PCR reactions as well as forward and reverse sequencings. As normal control, WT1 was analyzed in 50 unrelated adult volunteers whose urinalysis was normal.

Karyotype analysis or Y chromosome identification. To confirm the sex of patients, karyotype analysis was performed on four patients with WT1 mutations. For the two patients, for which karyotype analysis was not performed, SRY gene (specific marker on Y chromosome) was identified by amplifying SRY gene with PCR technique and confirmed by electrophoresis (13).

Abbreviations: CNS, congenital nephrotic syndrome; NS, nephrotic syndrome; SRNS, steroid-resistant nephrotic syndrome 


\section{RESULTS}

Clinical data. In the 36 children of the early-group, the ratio of male to female was 21:15. There were 19 children with onset age in the first year of life, of which five children with early onset age, $<3$ mo after birth (in accordance with the definition of CNS). There were 16 children with onset age between 1 and 2 y and one child with onset age between 2 and $3 \mathrm{y}$. In the 35 children of the control-group, the ratio of male to female was 23:12 (Table 2). There was no family history of renal diseases in 71 children of both the early and control-groups.

In 36 children of the early-group, renal biopsy, which was available for 15 childhood patients, revealed focal segmental glomerulosclerosis in 10 patients, minimal change lesions in three patients, and diffuse mesangial sclerosis in two patients. In the control-group, renal biopsy, which was available for 15 children, revealed focal segmental glomerulosclerosis in $12 \mathrm{pa}-$ tients and minimal change lesions in three patients (Table 2).

WT1 mutations in children of early-group and controlgroup. Of 36 children in the early-group, WT1 mutations (Table 3) were detected in six children (16.7\%). There were 19 of 36 children with onset age in the first year of life. Among the 19 children (10 girls), WT1 mutations were detected in five children (patients 1-5), of whom four were girls. In this subage group, the mutation detection rate was $26.3 \%$ (5/19), and the mutation detection rate in phenotypic girls was

Table 1. Sequences of primers used for PCRs

\begin{tabular}{|c|c|c|}
\hline Gene & Primer sequences $\left(5^{\prime} \rightarrow 3^{\prime}\right)$ & PCR products (bp) \\
\hline \multirow[t]{2}{*}{ Exon 1} & F: CAGCGCTGAACGTCTCCA & 573 \\
\hline & R: GGGTGTCCTAGAGCGGAGAG & \\
\hline \multirow[t]{2}{*}{ Exon 2} & F: CCCGTGGCTGGTTCAGAC & 339 \\
\hline & R: TGCCATTGGGGTAATGATTT & \\
\hline \multirow[t]{2}{*}{ Exon 3} & F: GCTCAGGATCTCGTGTCTCC & 328 \\
\hline & R: GTCTCGTGCCTCCAAGACC & \\
\hline \multirow[t]{2}{*}{ Exon 4} & F: ATGTGGAGGCTTGCACTTTC & 343 \\
\hline & R: ACCAACTAGGGGAAGGAGGA & \\
\hline \multirow[t]{2}{*}{ Exon 5} & F: CAGTGGGACTGGGGACTTAG & 328 \\
\hline & R: GAGATTCTTCCCATCCACCA & \\
\hline \multirow[t]{2}{*}{ Exon 6} & F: CCATCATTCCCTCCTGATTG & 329 \\
\hline & R: GAGCAGGTGTCCCTGATGTT & \\
\hline \multirow[t]{2}{*}{ Exon 7} & F: CAGTGCTCACTCTCCCTCAA & 314 \\
\hline & R: CCTGGGTCCTTAGCAGTGTG & \\
\hline \multirow[t]{2}{*}{ Exon 8} & F: TCCAGCGAAGTGCCTTAGGC & 407 \\
\hline & R: GGGGAAATGTGGGGTGTTTCC & \\
\hline \multirow[t]{2}{*}{ Exon 9} & F: TGCAGACATTGCAGGCATGGCAGG & 349 \\
\hline & R: GCACTATTCCTTCTCTCAACTGAG & \\
\hline \multirow[t]{2}{*}{ Exon 10} & F: AATTCAGAGTGGGTGCCTTG & 309 \\
\hline & R: TGAGGAGGAGTGGAGAGTCAG & \\
\hline
\end{tabular}

F, forward; $R$, reverse.
$40 \%$ (4/10). There were 16 of 36 children with onset age between 1 and $2 \mathrm{y}$ old, and only one child (patient 6, 1/16, $6.3 \%$ ) had a WT1 mutation detected in this subage group. Of 36 children, there was only 1 child with onset age between 2 and 3 y old, and no WT1 mutation was detected in this subage group. In control-group, no WT1 mutation was detected in all the 35 children. In addition, no WT1 mutation was detected in all the parents of the children in both the groups.

A WT1 (IVS9 + $4 \mathrm{C}>\mathrm{T}$ ) mutation along with a heterozygous NPHS2 variant $860 \mathrm{~A}>\mathrm{G}$ het leading to $\mathrm{Q} 287 \mathrm{R}$ was detected in an 8-mo-old girl (patient 2). Although the mutation analysis only detected NPHS2 variant in the girl's mother, she did not present proteinuria. In our previous study, NPHS2 gene was detected and analyzed in all children of the early and control groups, which showed an NPHS2 compound heterozygous mutation only in one child who had been excluding from this study group. There was no NPHS1 mutation detected in all five children with onset age of 3 mo after birth in the early-group (data not shown).

Karyotype analysis or $Y$ chromosome identification. Karyotype analysis or $\mathrm{Y}$ chromosome identification were performed on the six children with WT1 mutations, which showed 46, XY karyotype or Y chromosome in three of five phenotypic girls. Another two of five girls were revealed 46, $\mathrm{XX}$ karyotype or no Y chromosome. There was only one male (patient 5) on phenotype and genotype among the 6 children with WT1 mutations who had urinary-genital malformations. In addition, one of six children had dysembryoma (patient 6 , Table 3).

\section{DISCUSSION}

Early-onset NS represents a clinically refractory condition, in whom most are resistant to steroid and immunosuppressive therapy and tend to progress to end-stage renal disease. Several causative genes related to proteinuria have been identified and analyzed in the patients with early-onset NS or primary SRNS in many countries. The results suggested that, in these genes, NPHS1 mutations were mainly detected in CNS; WTI and NPHS2 might be more common in childhood SRNS (9-11). In European countries, the incidence of NPHS2 mutations in primary SRNS was 10-30\% (11). Nevertheless, in Asian countries such as Korea, Japan, and China, the incidence of NPHS2 mutations in sporadic SRNS was low $(14,15)$, which suggested that the relative frequency of these genetic defects might be influenced by patient ethnic origin.

Previous studies have confirmed that WT1 mutation was a well-known cause of Denys-Drash syndrome and Frasier syn-

Table 2. Distribution of age, renal pathology, and mutation in early-group and control-groups

\begin{tabular}{|c|c|c|c|c|c|c|c|}
\hline \multirow[b]{2}{*}{ Groups } & \multirow{2}{*}{$\begin{array}{c}\text { Age of } \\
\text { onset (mo) }\end{array}$} & \multirow{2}{*}{$\begin{array}{l}\text { Number of } \\
\text { patients }\end{array}$} & \multicolumn{2}{|c|}{ Sex } & \multirow{2}{*}{$\begin{array}{c}\text { Renal biopsy } \\
\text { FSGS/MCL/DMS }\end{array}$} & \multirow{2}{*}{$\begin{array}{l}\text { Number of patients } \\
\text { with WT1 mutations }\end{array}$} & \multirow{2}{*}{$\begin{array}{c}\text { Number of patients } \\
\text { with ESRD }\end{array}$} \\
\hline & & & M & $\mathrm{F}$ & & & \\
\hline \multirow[t]{4}{*}{ Early-group } & $<3$ & 5 & 2 & 3 & $1 / 0 / 1$ & 1 & 1 \\
\hline & $4-12$ & 14 & 7 & 7 & $3 / 1 / 0$ & 4 & 2 \\
\hline & $13-24$ & 16 & 11 & 5 & $5 / 2 / 1$ & 1 & 2 \\
\hline & $25-36$ & 1 & 1 & 0 & $1 / 0 / 0$ & 0 & 0 \\
\hline Control-group & $>36$ & 35 & 23 & 12 & $12 / 3 / 0$ & 0 & 8 \\
\hline
\end{tabular}

F, female; M, male; FSGS, focal segmental glomerulosclerosis; MCL, minimal change lesion; DMS, diffuse mesangial scleroses; ESRD, end-stage renal disease. 
Table 3. Clinical data of patients with WT1 mutations

\begin{tabular}{|c|c|c|c|c|c|c|c|c|c|c|}
\hline Cases & $\begin{array}{c}\text { Phenotype/ } \\
\text { karyotype }\end{array}$ & $\begin{array}{l}\text { Onset age } \\
\quad(\mathrm{mo})\end{array}$ & $\begin{array}{l}\text { Diagnosis } \\
\text { age (y) }\end{array}$ & Edema & $\begin{array}{c}\text { Proteinuria } \\
(\mathrm{mg} / \mathrm{kg} .24 \mathrm{~h})\end{array}$ & $\begin{array}{l}\text { Age at } \\
\text { CRF }\end{array}$ & $\begin{array}{c}\text { Renal } \\
\text { pathology }\end{array}$ & Therapy & WT1 mutation & Genital status \\
\hline $\mathrm{P} 1$ & $\mathrm{~F} / 46, \mathrm{XX}$ & 3 & 2.0 & Eyelid & $4+/ 198.0$ & No (3 y) & FSGS & SR CsA/NR & $\operatorname{IVS} 9+5 \mathrm{G}>\mathrm{A}$ & Female, normal \\
\hline $\mathrm{P} 2$ & $\mathrm{~F} / 46, \mathrm{XY}$ & 8 & 1.5 & Eyelid & $3+/ \mathrm{NA}$ & Yes $(8 \mathrm{mo})$ & NA & PD & IVS9 $+4 \mathrm{C}>\mathrm{T}$ & $\begin{array}{l}\text { Female, streak } \\
\text { gonads }\end{array}$ \\
\hline P3 & $\mathrm{F} / 46, \mathrm{XY}$ & 12 & 8.0 & Eyelid & $3+/ 221.4$ & No $(11 \mathrm{y})$ & FSGS & SR CsA/NR & IVS $9+5 \mathrm{G}>\mathrm{A}$ & $\begin{array}{l}\text { Female, streak } \\
\text { gonads }\end{array}$ \\
\hline P4 & $\mathrm{F} / 46, \mathrm{XX}$ & 12 & 1.3 & No & $3+199.0$ & No (1.3 y) & NA & SR CTX/NR & IVS $9+5 \mathrm{G}>\mathrm{A}$ & Female, normal \\
\hline P5 & $\mathrm{M} / 46, \mathrm{XY}$ & 6 & 0.6 & Eyelid & $4+/ \mathrm{NA}$ & No $(1 \mathrm{y})$ & NA & SR & $1186 \mathrm{G}>\mathrm{A}$ het, $\mathrm{D} 396 \mathrm{~N}$ & $\begin{array}{l}\text { Hypospadias } \\
\text { cryptorchidism }\end{array}$ \\
\hline P6 & $\mathrm{F} / 46, \mathrm{XY}$ & 24 & 4.8 & No & $4+/ 90.5$ & No $(4.8 \mathrm{y})$ & FSGS & SR MMF/ NR CTX/NR & IVS $9+5 \mathrm{G}>\mathrm{A}$ & Dysembryoma \\
\hline
\end{tabular}

F, female; M, male; FSGS, focal segmental glomerulosclerosis; SR, steroid resistant; NA, not available; CRF, chronic renal failure; NR, no responsive; PD, peritoneal dialysis; CTX, cyclophosphamide; CsA, cyclosporine; MMF, mycophenolate mofetil; het, heterozygous.

drome, which are rare diseases. In recent years, studies indicated that de novo mutations in exons 8 and 9 of the WT1 gene might be the causative gene for sporadic SRNS. Some studies reported that the incidence of WTI mutations in isolated SRNS children younger than 18 y was $6-7 \%(9,10)$. Nevertheless, WT1 mutation in children with early-onset NS was only reported from two study groups. Hinkes et al. (16) reported that the prevalence of WT1 mutations in NS manifesting in the first year of life was 3.8\%, and Sako et al. (17) reported that no WT1 mutation was detected in Japanese children with CNS. In China, the incidence and the phenotypic features of children with WT1 mutations, especially in children with early-onset NS are unknown. In this study, the prevalence of WT1 mutations in children of early-group was $16.7 \%$ ( 6 of 36 children). Furthermore, in subage groups, the mutation detection rates of WT1 were $26.3 \%(5 / 19), 6.3 \%$ $(1 / 16)$, and $0(0 / 1)$ in children of younger than $1 \mathrm{y}, 1-2 \mathrm{y}$, and 2-3 y, respectively. The WT1 mutation seemed predominant in girls, onset age younger than 1-y-old $(40.0 \%$ detection rate in this study). However, no WTI mutation was detected in children of the control-group, and the result suggested that, in Chinese children younger than $1 \mathrm{y}$, the rate of WT1 mutations was obviously higher than that reported in European countries (3.8\%) (16). In CNS, $1 / 5$ (20.0\%) children were found to have the WT1 mutation in this study, whereas no WT1 mutation was detected in 13 Japanese children (17). Therefore, we proposed to carry out the detection of WT1 mutation in Chinese children with early-onset NS, especially in female phenotypic children with onset age in the first year of life.

Patients with WTI mutations exhibited an inconsistency between the extent of edema and the levels of proteinuria. In six children with WT1 mutations and predominantly massive proteinuria, four of them presented with intermittent eyelid edema and two of them developed proteinuria without edema. Similar presentation features were also described in previous studies reported by others $(9,10,14)$. On the contrary, patients with NPHS1 or NPHS2 mutations often presented with severe anasarca and massive proteinuria.

The WT1 gene encodes a nuclear zinc finger domain, which is significant to normal kidney and gonadal system development, especially in male patients (18). In a number of studies, including our investigation, children of the 46, XY karyotype with WT1 mutations developed NS with genitourinary malformation, including abnormal extra-genitourinary manifesta- tions and pseudohermaphroditism. Children of the 46, XX karyotype with WT1 mutations often developed NS without genitourinary anomalies. These results suggest that male phenotypic children with WT1 mutations tend to have genitourinary malformations. In other words, for children with the normal 46, XY phenotypic male, the probability of WTI mutations was rare and WT1 mutational analysis is not regularly recommended. Compared with children without the WTI mutation, there was no significant difference on the renal pathology.

In this study, WT1 mutation combined with NPHS2 variant was detected in a girl. The child presented with some characters of Frasier syndrome, such as male pseudohermaphroditism and the WT1 IVS 9+4 C>T mutation. However, renal failure occurred at 8 mo of age, which was earlier than other children of the Frasier syndrome reported previously by other authors. The girl also had an NPHS2 variant $(860 \mathrm{~A}>\mathrm{G}$ het leading to Q287R) in the conserved region of podocin, which had not been detected in 50 unrelated adult volunteers of Chinese ancestry and has not been reported by other studies. Thus, we speculate that the deterioration of renal function might be accelerated by two mutations of NPHS2 and WT1 genes. Di-genic heterozygosity has been reported in some patients, including NPHS2 combined with NPHS1 or CD2AP mutations, and a mutation in NPHS1 combined with a WTI mutation $(19,20)$. Our study, for the first time, demonstrated the di-genic heterozygosity of NPHS2 mutation combined with a WT1 mutation might exist in Chinese patients with NS. Nevertheless, the clinical implication of the di-genic heterozygosity as well as the interaction of the two genes and the role of the combined genetic defects in the onset and severity of proteinuria is still unclear. Therefore, further study is needed to clarify the pathogenic role of the di-genic heterozygosity in NS.

In conclusion, our study demonstrates that WT1 mutations seemed more common in Chinese children with early-onset NS and more WT1 mutations were detected in Chinese female NS children with early-onset age. The child with WT1 mutation and single heterozygous NPHS2 variant is the first report in the literature, which showed earlier renal failure. The pathogenesis of WT1 mutation combined with NPHS2 mutation still needs to be investigated.

Acknowledgments. We owe our humblest gratitude to the physicians who referred patients to our department. We also 
sincerely thank all of the doctors and nurses of the Division of Pediatric Nephrology, Peking University First Hospital who assisted us in this study.

\section{REFERENCES}

1. Kestila M, Lenkkeri U, Mannikko M, Lamerdin J, McCready P, Putaala H, Ruotsalainen V, Morita T, Nissinen M, Herva R, Kashtan CE, Peltonen L, Holmberg C, Olsen A, Tryggvason K 1998 Positionally cloned gene for a novel glomerular protein-nephrin-is mutated in congenital nephrotic syndrome. Mol Cell 1:575-582

2. Boute N, Gribouval O, Roselli S, Benessy F, Lee H, Fuchshuber A, Dahan K, Gubler MC, Niaudet P, Antignac C 2000 NPHS2, encoding the glomerular protein podocin, is mutated in autosomal recessive steroid-resistant nephrotic syndrome. Nat Genet $24: 349-354$

3. Klamt B, Koziell A, Poulat F, Wieacker P, Scambler P, Berta P, Gessler M 1998 Frasier syndrome is caused by defective alternative splicing leading to an altered ratio of WT1 KTS splice isoforms. Hum Mol Genet 7:709-714

4. Zenker M, Aigner T, Wendler O, Tralau T, Müntefering H, Fenski R, Pitz S, Schumacher V, Royer-Pokora B, Wühl E, Cochat P, Bouvier R, Kraus C, Mark K, Madlon H, Dötsch J, Rascher W, Maruniak-Chudek I, Lennert T, Neumann LM, Reis A 2004 Human laminin $\beta 2$ deficiency causes congenital nephrosis with mesangial sclerosis and distinct eye abnormalities. Hum Mol Genet 13:2625-2632

5. Hinkes B, Wiggins RC, Gbadegesin R, Vlangos CN, Seelow D, Nürnberg G, Garg P, Verma R, Chaib H, Hoskins BE, Ashraf S, Becker C, Hennies HC, Goyal M, Wharram BL, Schachter AD, Mudumana S, Drummond I, Kerjaschki D, Waldherr R, Dietrich A, Ozaltin F, Bakkaloglu A, Cleper R, Basel-Vanagaite L, Pohl M, Griebel M, Tsygin AN, Soylu A, Müller D, Sorli CS, Bunney TD, Katan M, Liu J, Attanasio M, O'toole JF, Hasselbacher K, Mucha B, Otto EA, Airik R, Kispert A, Kelley GG, Smrcka AV, Gudermann T, Holzman LB, Nürnberg P, Hildebrandt F 2006 Positional cloning uncovers mutations in PLCE1 responsible for a nephrotic syndrome variant that may be reversible. Nat Genet 38:1397-1405

6. Kaplan JM, Kim SH, North KN, Rennke H, Correia LA, Tong HQ, Mathis BJ, Rodríguez-Pérez JC, Allen PG, Beggs AH, Pollak MR 2000 Mutations in ACTN4, encoding $\alpha$-actinin-4, cause familial focal segmental glomerulosclerosis. Nat Genet 24:251-256

7. Winn MP, Conlon PJ, Lynn KL, Farrington MK, Creazzo T, Hawkins AF, Daskalakis N, Kwan SY, Ebersviller S, Burchette JL, Pericak-Vance MA, Howell DN, Vance JM, Rosenberg PB 2005 A mutation in the TRPC6 cation channel causes familial focal segmental glomerulosclerosis. Science 308:1801-1804

8. Kim JM, Wu H, Green G, Winkler CA, Kopp JB, Miner JH, Unanue ER, Shaw AS 2003 CD2-associated protein haploinsufficiency is linked to glomerular disease susceptibility. Science 300:1298-1300
9. Aucella F, Bisceglia L, De Bonis P, Gigante M, Caridi G, Barbano G, Mattioli G, Perfumo F, Gesualdo L, Ghiggeri GM 2006 WT1 mutations in nephrotic syndrome revisited. High prevalence in young girls, associations and renal phenotypes. Pediatr Nephrol 21:1393-1398

10. Ruf RG, Schultheiss M, Lichtenberger A, Karle SM, Zalewski I, Mucha B, Everding AS, Neuhaus T, Patzer L, Plank C, Haas JP, Ozaltin F, Imm A, Fuchshuber A, Bakkaloglu A, Hildebrandt F; APN Study Group 2004 Prevalence of WT1 mutations in a large cohort of patients with steroid-resistant and steroid-sensitive nephrotic syndrome. Kidney Int 66:564-570

11. Karle SM, Uetz B, Ronner V, Glaeser L, Hildebrandt F, Fuchshuber A 2002 Nove mutations in NPHS2 detected in both familial and sporadic steroid-resistant nephrotic syndrome. J Am Soc Nephrol 13:388-393

12. Li J, Zhao D, Ding J, Xiao H, Guan N, Fan Q, Zhang H 2007 WT1 mutation and podocyte molecular expression in a Chinese Frasier syndrome patient. Pediat Nephrol 22:2133-2136

13. Harley VR, Clarkson MJ, Argentaro A 2003 The molecular action and regulation of the testis-determining factors, SRY (sex-determining region on the Y chromosome) and SOX9 [SRY-related high-mobility group (HMG) box 9]. Endocr Rev 24:466487

14. Cho HY, Lee JH, Choi HJ, Lee BH, Ha IS, Choi Y, Cheong HI 2008 WT1 and NPHS2 mutations in Korean children with steroid-resistant nephrotic syndrome. Pediatr Nephrol 23:63-70

15. Maruyama K, Iijima K, Ikeda M, Kitamura A, Tsukaguchi H, Yoshiya K, Hoshii S, Wada N, Uemura O, Satomura K, Honda M, Yoshikawa N 2003 NPHS2 mutation in sporadic steroid-resistant nephrotic syndrome in Japanese children. Pediatr Nephrol 18:412-416

16. Hinkes BG, Mucha B, Vlangos CN, Gbadegesin R, Liu J, Hasselbacher K, Hangan D, Ozaltin F, Zenker M, Hildebrandt F; Arbeitsgemeinschaft für Paediatrische Nephrologie Study Group 2007 Nephrotic syndrome in the first year of life: two thirds of cases are caused by mutations in 4 genes (NPHS1, NPHS2, WT1, and LAMB2). Pediatrics 119:e907-e919

17. Sako M, Nakanishi K, Obana M, Yata N, Hoshii S, Takahashi S, Wada N, Takahashi Y, Kaku Y, Satomura K, Ikeda M, Honda M, Iijima K, Yoshikawa N 2005 Analysis of NPHS1, NPHS2, ACTN4, and WT1 in Japanese patients with congenital nephrotic syndrome. Kidney Int 67:1248-1255

18. Hammes A, Guo JK, Lutsch G, Leheste JR, Landrock D, Ziegler U, Gubler MC, Schedl A 2001 Two splice variants of the Wilms' tumor 1 gene have distinct functions during sex determination and nephron formation. Cell 106:319-329

19. Mao J, Zhang Y, Du L, Dai Y, Gu W, Liu A, Shang S, Liang L 2007 NPHS1 and NPHS2 gene mutations in Chinese children with sporadic nephrotic syndrome. Pediatr Res 61:117-122

20. Löwik M, Levtchenko E, Westra D, Groenen P, Steenbergen E, Weening J, Lilien M, Monnens L, van den Heuvel L 2008 Bigenic heterozygosity and the development of steroid-resistant focal segmental glomerulosclerosis. Nephrol Dial Transplant 23:3146-3151 